\title{
INNOVATION IN THE BUSINESS MODEL FROM THE PERSPECTIVE OF DYNAMIC CAPABILITIES: BEMATECH'S CASE
}

\author{
ELIC VODOVOZ \\ Universidade Federal do Paraná (UFPR). \\ MÁRCIA RAMOS MAY \\ Universidade Federal do Paraná (UFPR).
}

To cite this paper: Vodovoz, E. \& May, M. R. (2017). Innovation in the Business Model from the perspective of Dynamic Capabilities: Bematech's case. Revista de Administração Mackenzie, 18(6), 71-95. doi 10.1590/1678-69712017/administracao.v18n6p71-95 


\section{ABSTRACT}

Purpose: The literature on business models deals with creation and capture of the value obtained through innovation as elements necessary for the continuity of the companies. The concepts inherent in business models demonstrate the operation logics $s$ for the creation of value. To verify how the value creation process occurs, a case study has been carried out based on the change in the business model of Bematech S.A, a Brazilian company from Information Technology (IT) service area.

Originality/Value: The theory about business models and dynamic capabilities indicates some connections between these concepts, but this connection lacks practical observation, so the purpose of this article is to understand how innovation occurred in the business model and search, which routines were essential for the value creation in the company Bematech. The phenomenon was observed from the perspective of dynamic capacities.

Design/methodology/approach: Based on the reviewed literature, it was decided to conduct in-depth interviews with employees from the strategic planning and IT areas. A graphical representation of the business model was used to capture its structure, the business model canvas.

Findings: The results of this study show how dynamic capability and business model connections occur and demonstrate which high-level routines enabled innovations in the Bematech's business model for value creation and value capture. The study also shows the boundary between dynamic capabilities and the business model.

\section{KEYWORDS}

Business model. Dynamic capabilities. Value creation. Value capture. Routines. 


\section{INTRODUCTION}

In the scenario today, managers must be able to organize multiple distribution channels, complex supply chains, rare technological resources, and yet remain flexible enough to shape the changing market. In this situation of increasing complexity, the business model theme has acquired importance as a way of explaining the functioning of an organization considering the components of its strategy, an accessible option to understand or manage a business by its main processes and routines (Cavalcante, Kesting, \& Ulhøi, 2011).

This understanding is possible through logical representation of how value is delivered to the companies' customers. This broad view of a business is called a business model (OSTERWALDER; PIGNEUR, 2010). Its construction allows identifying how a particular enterprise is implemented, how one can capture value from it and the structure necessary for this.

By observing the influence of the business model in the strategic base of the company flexibility in technology changing environments and market (Bock, Opsahl, George, \& Gann, 2012), it is desirable to analyze how this relationship has been built and the changes designed over time. In this case, the concept of dynamic capacities is adapted to the role of analysis lens, in order to understand the behavior of the actors inherent in the process of changing business models (TEECE, 2010).

In this context, Teece (2007) argues that through the development of dynamic capabilities, it is possible to identify and reconfigure competencies that the company needs to act in an environment of constant change.

Despite of the author's assertion, some practical questions remain about the connections between the concepts of dynamic capabilities and business models, that is, the positioning of dynamic capacities in relation to business models in a real case. In the theoretical scope, the answer to these questions can direct the study of these concepts and help understanding the boundaries between them. In the organizational sphere, this clarity can help in the process of innovation on business models, that is, in the constitution of methodologies or technical tools oriented to innovation in business models.

Therefore, the purpose of this article is to understand how innovation has occurred in the business model and what routines have been essential in the search for the creation of the Bematech's values. The phenomenon is observed from the perspective of dynamic capacities. 


\section{BUSINESS MODEL}

The concept of business model is not unanimous among authors, as Zott, Amit, and Massa (2011) affirms. However, points of convergence are observed between the various definitions found in articles and books. The theorists understand the business model as a concept directly related to creation, delivery and capture of value (OSTERWALDER; PIGNEUR, 2010).

As a way to facilitating the understanding about organizations, Petrovic et al. Kittl. (2001) perceive the business model as a description of a complex business that enables studying the structure, the relationship between the structural elements and how these elements respond in the real world. In this context, Stahler (2002) states that a model is always the simplification of a complex reality and helps to understand the fundamentals of a business or to plan how a business should behave in the future.

In the same context, Magretta (2002) treats the business model as a story that explains how a company works, that is, describes how the "parts" of a business are interconnected.

The difficulty to represent all business model elements made Osterwalder (2004) try to unify the concepts in building blocks of the business model, to represent the value creation logics in a tool known as Business Model Canvas. To do so, they used the existing literature as a basis to design the analysis tool that contemplates the set of elements of the business model and their relations to express the logic about how a company makes money. Therefore, the business model canvas is seen as a visual representation of the relationships between the business model elements to facilitate understanding of the value delivered to the customer segments, the organizational architecture of the company and its network of partners.

In addition to facilitating the understanding of the business, the visualization of the business model with the help of representation by the tool, brought the possibility to understand the business model in its structural aspect, that is, the structural design of the company (Baden-Fuller \& Morgan, 2010) for the exploration of new business opportunities, indicating the possibilities of generating value through a systemic analysis aimed at the innovation of organizations (ZOOT; MASSA, 2011; OSTERWALDER; PIGNEUR, 2010; Cavalcante, S., Kesting, P., \& Ulhøi, J 2011).

\subsection{Canvas Business Model Template}

In the analysis performed in this work, the nine blocks idealized by Osterwalder and Pigneur (2010) have been used as a graphical representation 
of the business model. The business model (Canvas) is the analysis tool selected for this study, since it is the one that presents the greatest theoretical comprehension among the representations of the analyzed business models (Vodovoz, 2015). Thus, the components of the Canvas business model are detailed:

- Customer segment: Individuals or entities that purchase the goods or services.

- Value proposition: The value proposition is at the heart of the business model. This positioning reflects "what" the company offers to solve the problem or meet the customer's need.

- Channels: Channels describe how the company delivers products to customers, how the value proposition reaches the customer.

- Customer relationship: the customer relationship block describes what extent of loyalty the company expects to maintain with their customers.

- Revenue sources: are the ways revenues enter. This block describes how the money paid by customers reaches the company.

- Key Features: A pack of key features explains what are the main features that keep the operation of the business model.

- Key activities: are activities in which the company must be proficient to keep the business model.

- Key partnerships: are ways to maximize reach or even enable a business model.

- Cost Structure: The cost structure describes the value that is necessary for the operation of the business model; in an objective way, costs are concentrated on key activities, key resources and partnerships.

\section{CONCEPT OF VALUE}

In the field of strategic management, value has been used to explain the search for competitive advantages of organizations in two chains of thought: Porter (1985) and Barney (1991). However, there is still no common concept about value (Barney \& Arikan, 2001; Bowman \& Ambrosini, 2000).

For Porter (1985), in his perspective known as the Strategic Positioning Analysis (SPA), the essence of competitive advantage is the highest value customers are willing to pay in relation to the company manufacturing cost.

According to Barney (1991), and based on the concept of resource-based Vision (RBV), competitive advantage is achieved by a company when its value creation strategy cannot be easily copied by competitors.

The work on dynamic capabilities commonly uses terms, such as value creation and value capture. It is known that the definition of value in the view 
of the dynamic capabilities is influenced by the Barney's current (1991), in which the value is related to valuable resources, rare, difficult to imitate or replace. However, it is perceived that the dynamic capabilities also relate the creation of value to high-level routines based on the entrepreneurial activity of identifying opportunities and resource mobilization, implementation of business models (Augier \& Teece, 2008), processes, leadership ability applied to these resources (Teece, 2014).

However, RBV lacks studies about the creation and capture of value for understanding the phenomenon in strategic management (Kraaijenbrink, Spender, \& Groen, 2010). In the search to fill these gaps, one option is to invoke other theoretical lenses such as the dynamic capabilities.

\subsection{Value creation and value capture}

The ability to create value does not guarantee the persistent performance of the company's activity, since there are external to the company factors, such as competition, for example. For a long-term activity, the organization must be effective in creating and capturing value. This is because the created value may be different from the captured value, and often so is the company can create value but may fail to capture value.

The literature shows that several authors indicate elements and processes they consider important in the creation of value in the organizational scope. For Boulton, Libert and Samek (1997, 2000), value creation comes not from a single enterprise resource, but from the integration of all organizational elements.

When facing the same perspective, Lindgreen, Hingley, Grant, and Morgan (2012) point out that the relationships between organizational resources, whether tangible or intangible, are the central elements of the value creation process.

According to Leih, Linden, and Teece (2014), the capture of value depends on an architecture that combines strategies of entry, integration, cooperation and diversification with the organizational design in harmony with these strategies, that is, the creation of value from processes or routines of highlevel capabilities that enable organizations to review and develop capabilities for long-term value creation and capture.

In this context, the creation of value handled in this work moves away from mathematical exchanges insofar as the value created is influenced by the processes of transformation, capacity to identify the opportunities and the clients' needs and the combination and transformation of resources (Anderson, Nars 1998; ZEITHAMAL, 1998, Penrose, 1995). These key 
elements for creating and capturing value, as well as the role of the manager in creating the essential routines in value creation and capture processes, are addressed in the next section under the lens of dynamic capabilities.

\subsection{Dynamic capabilities}

The vision of the dynamic capacities takes care of the adaptive aptitude of the firm in a dynamic environment (Teece \& Pisano, 1994; TEECE; PISANO; SHUEN, 1997). It is the organizational capacity to detect, integrate, learn and reconfigure its internal or external resource base, whether knowledge, skills or strategies, to adapt and respond to the demands of a constantly changing environment (TEECE; 2010, 2012).

Teece and Pisano (1994) developed the theme based on RBV. According to Barney (1991) and Grant (1996), organizational resources considered difficult to reproduce by other competitors, when used for value generation, can generate competitive advantages. The dynamic capabilities perspective has added the external component and importance of strategic capacity management, proposing greater flexibility to develop new capabilities for $\mathrm{RBV}$, as well as renewing existing ones with the purpose to generate competitive advantages. Even though, the resources employed are scarce or difficult to replicate (TEECE; PISANO; SHUEN, 1997; Eisenhardt \& Martin, 2000; Augier \& Teece, 2008).

In the same context, in a more recent approach, dynamic capabilities are determinant for the speed and degree to which companies align and realign their resources to meet the needs of the environment, as well as to seize the opportunities generating sustainability and advantages over to competitors (TEECE, 2007, 2012).

In order for this to happen, the companies' actions should be focused on: a) processes of integration and alignment of resources (TEECE, 2012), understanding internal processes in their congruence and complementarities, that is, integration between processes and organization with the help of logic; b) learning - processes that are performed repeatedly, improve the efficiency of the organization and enable identification of dysfunctions c) adaptation - running well-organized learning processes, such as benchmarking, in order to gain competitive advantage in dynamic environments and develop the ability to learn from the organization to be a routine practice; thus, organizations with dynamic capabilities are always observing the changes in the environment by evaluation of the markets and competitors and consequently, they are able to adapt to the changes more easily (Teece \& Pisano, 1994). 
The concepts advocated by dynamic capabilities approximate those found in Teece's (2010) business and value-creation models when they claim that the generated competitive advantages depend on the increase in value resulting from high-level routines that enable firms to reconfigure their resources, identify and exploit opportunities, synchronize processes with business models to shape the environment in their favor (LEIH; LINDEN; TEECE, 2014).

In summary, Leih, Linden, and Teece (2014) argue that understanding dynamic capabilities is fundamental, since they represent the basis for creating and capturing value through high-level routines.

The literature lists two types of capacities: Ordinary capacities and dynamic capacities (Winter, 2003). Ordinary or operational capacities encompass operational, administrative and governance activities that ensure the organization's ability to exist (production and sale of products and services) (Lehi and Linden, Teeche, 2014). Dynamic capacities represent high-level routines; they differ from ordinary capacities, but are interrelated in a hierarchical relationship because dynamic capacities are those capable of reconfiguring and creating new combinations of operational capacities to maintain the relevance of these ordinary capacities in turbulent environments (PAVLOU; SAWY, 2011). An improvement in ordinary capacities can bring greater efficiency of activities; however, dynamic capacities are the only ones capable of creating value and competitive advantages when combined with a solid strategy as well as a good execution and allow the company to develop the ideal products in relation and are critical for entry into new markets (TEECE, 2012).

1. From this perspective, the dynamic capabilities view points to the existence of three groups of management processes that can be used to identify opportunities for value capture and continuous renewal in accelerated change environments. These are the types of high-level routines (TEECE, 2007, 2012):

2. Sensing - routines to identify and evaluate opportunities.

3. Seizing - Routines for integration of resources aiming at coordination for the capture of value from the new opportunity.

4. Transforming - Routines for organizational renewal.

These stages are interconnected and can be verified in the innovation of business models, as well as in their creation and implementation of new models (Leih, Linden, \& Teece, 2014). 
Taking into account the concepts of creation and capture of value and establishing a connection with the dynamic capabilities, according to Katkalo, Pitelis, and Teece (2010), the activities incorporated in the highlevel routines can be grouped into two classes: Value, referring to the ability to use resources, such as technology, for value creation and those that seek to capture value through organizational design determined by diverse strategies, such as cooperation, integration and diversification.

Therefore, the approach of the routine concepts, the role of the manager in the development of dynamic capacities that can change the business model and the capacities observed during the analysis of the process of change in the Business model of the company.

\subsection{Routines}

One of the possible meanings for the word "routine" is that of an action that repeats sequentially as a constant practice. In relation to organizations, routines are based on sequential activities for tasks to be performed, but routines can be linked to organizational change capabilities through learning (Fenderman and Penton, 2003). Although routinely bring the idea of rigidity, routines can present flexibility under conditions of environmental turbulence and adapt (TEECE, 2012).

The dynamic capabilities are related to the high-level routines and present a strategic character, different from the operational routines that represent the ordinary capacities, responsible for execution of processes and not for identification, prioritization and selection of processes. Ordinary capacities are essentially responsible for the company's operational activities, they maintain the efficiency of activities (TEECE, 2012). The high-level routines resulting from dynamic capabilities allow the company to prepare to manufacture products with the best value proposition for customers and take advantage of future technological opportunities (TEECE, 2012), they are responsible for the ways how information and experiences will be harnessed, the exchange of experience between clients and the organization or coordination of resources (Teece \& Pisano, 1994). In this context, the common capabilities are directly linked to the resources that will be reconfigured by dynamic capabilities (Helfat et al., 2009).

Therefore, ordinary capacities are at a lower level if compared to the dynamic capabilities of producing routines that integrate resources and reconfigures them through the organizational learning process to generate competitive advantages (Henderson \& Cockburn, 1994; TEEPE; PISANO; SHUEN, 1997). 


\subsection{Role of the manager in dynamic capacities}

Although business model changes occur due to the dynamic capabilities found at various levels of the organization (LEIH, LINDEN, TEECE, 2014), in most cases, certain dynamic capabilities may be the result of the experience of a selected group within the organization. Usually, these people are the managers or the entrepreneurs, whose role is to implement routines that enable alignment of resources to achieve goals and take advantage of opportunities in the environment, where the company is inserted, that is, to integrate, to build and to reconfigure internal or external competences or resources on rapidly changing environments (TEECE, 2012).

In this context, the managers are the ones, who verify opportunities for changes in the business model, such as the moment of establishing new partnerships with the help of high-level routines resulting from the development of dynamic capacities to probe new scenarios, verify possibilities and enable opportunities for resources at their disposal (TEECE, 2012).

Therefore, one can emphasize the participation of leaders, entrepreneurs, managers and their groups responsible for the development of business models of sensing, seizing and transforming activities to sustain dynamic capabilities, drawing the routines, coordinating the resources (TEECE, 2012).

\section{METHODOLOGY}

The question that motivated this study was the identification of the high-level routines that act in the creation of value in the business model of the investigated company. For this purpose, exploratory qualitative approach with a single case study was used. Two cuts were made. An initial cut before the change in the business model, and another one after the change in the business model.

Based on the reviewed literature, it was decided to carry out in-depth interviews with company employees, who had the necessary information to study in the areas of information technology, Strategy and operations.

In order to capture the structure of the organization's initial business model and the post-change model, we used the canvas model structured together with employees and managers from the company. Information for the development of business model representations was complemented by analyzing documents, telephone interviews, e-mail exchange with managers in the procurement, human resources and investor relations sectors.

Based on the collection of information about the business model and its changes, the dynamic capacities were identified using the Pavlou and 
El Sawy (2011) model, submitting the questionnaire used by these authors to the key agents in the company acting in the high-level strategic decisions, as adoption or acquisition and use of technology aiming at finding highlevel routines for the identification, learning, integration, coordination, reconfiguration dynamic capabilities.

In summary, the survey of the information of the high-level routines was done through the interviews, research in the corporate website and documents presented by the investor relations sector of the analyzed company. To this end, Bematech was selected because it experienced singular technological and strategic changes in its business model.

\section{RESULTS AND ANALYSIS}

The results are presented starting from analysis and comparison of the initial business model and the one verified until the closing of the data collection. In addition, the routines developed by the company are examined. At the end, a parallel is made between the business model and the dynamic capabilities of the company.

\subsection{Bematech's Business Model}

The analysis of Bematech's business models starts with the presentation of aspects of the initial model of the organization, which can be observed in the canvas model in Figure 1 filled in black. The company specialized in dot-matrix printers. In its value proposition, the model contemplated banking printers, fiscal printers and other hardware, such as keyboards, computers, monitors, sold together or separately to retail customers. During this period, banks were the company's main customers. Due to the fiscal requirements, the printer started to be used at points of sale, a great opportunity for growth in the retail market.

The main sales channels were represented by resellers, but there were still direct sales to customers, such as financial institutions.

The relationship was made mainly indirectly by the resellers because since the beginning, Bematech outsourced its service channels, except for the most potential clients that established service contracts without intermediaries. Assistance services were outsourced in the same way as resellers. The direct channel with Bematech was customer service over the phone.

As for activities, you could check the search for the company's growth based on innovation activities and developing partnerships with resellers, 
hardware vendors and representatives of service providers, in order to increase sales.

Over the years, there have been changes in the company's organizational capabilities as a result of innovation in the business model.

\section{(Figure 1)}

CURRENT BUSINESS MODEL BEMATECH

\begin{tabular}{|c|c|c|c|c|}
\hline $\begin{array}{l}\text { Key } \\
\text { Partners } \\
\text { - Hardware } \\
\text { suppliers } \\
\text { - Business } \\
\text { assistance } \\
\text { - Software } \\
\text { house } \\
\text { - Software } \\
\text { companies } \\
\text { - Internal } \\
\text { developers }\end{array}$ & $\begin{array}{l}\text { A. Key } \\
\text { - Contract for } \\
\text { services } \\
\text { - Technical } \\
\text { development } \\
\text { - Acquisition of } \\
\text { technology } \\
\text { - Develop and } \\
\text { maintain } \\
\text { partnerships } \\
\text { - Incorporations } \\
\text { - Sales } \\
\text { - Innovation } \\
\text { - Software } \\
\text { development } \\
\text { - } \\
\text { \& Key } \\
\text { - E Resources } \\
\text { - Employees } \\
\text { Physical } \\
\text { structure } \\
\text { - Acquired } \\
\text { experience } \\
\text { - IT equipment } \\
\text { - Factory } \\
\text { - Developers } \\
\text { - Software } \\
\text { ownership }\end{array}$ & $\begin{array}{l}\text { U Value } \\
\text { - Printers } \\
\text { - Other hardwares } \\
\text { - Modular } \\
\text { automation } \\
\text { systems } \\
\text { - ERP in the } \\
\text { cloud } \\
\text { - Cloud services }\end{array}$ & $\begin{array}{l}\text { Customer } \\
\text { - Technical assistance } \\
\text { - Internet } \\
\text { - Relationship center } \\
\text { - Internet } \\
\text { - Continuous } \\
\text { - follow-up } \\
\text { - Contract for services } \\
\text { - Technical assistance } \\
\text { - Advantage program }\end{array}$ & $\begin{array}{l}\text { I Customer } \\
\text { - Retail } \\
\text { - Corporate } \\
\text { - Food service } \\
\text { - Ground } \\
\text { transportation } \\
\text { - Hospitality }\end{array}$ \\
\hline 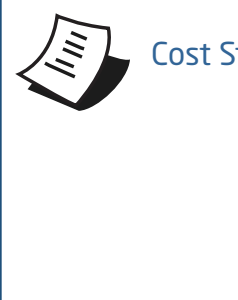 & cture & & $\begin{array}{l}\text { Revenue Streams } \\
\text { dware sales } \\
\text { tware sales } \\
\text { training } \\
\text { tware licence } \\
\text { ud services }\end{array}$ & \\
\hline
\end{tabular}


After the changes perceived in Figure 1, in red, there was an increase in the complexity of the business model, as a result of the increase of the new operational capabilities. In the new model there are new value propositions represented in a concept of one-stop-shop, meaning the supply of complete solutions for business automation. Therefore, Bematech started selling complete packages of software and hardware. The most significant changes to the initial model took place in the value proposition and customer segment: software offers and cloud solutions focused on customers by certain vertical clients, rather than center on products. Thus, the teams are distributed among verticals: Corporate, food service and retail. In this new model, the activities standing out are those related to acquisitions that add value to the business model, developing partnerships with resellers, distributors and software houses in order to increase the reach and meet the company's growth strategy.

One innovation of the new model is the existence of new digital channels for relationship with customers and partners, such as "Bematech Plus", a relationship program and Bematech University, an initiative to empower partners and bring greater synergy to the processes.

It is a partner-based model to sell products and services, provide support and develop solutions for customers. All partners powers are highly dependent on partners model, especially resales and software houses.

According to the director of investor relations, Bematech's main strategies are focused on expanding the customer base, always focusing on small and medium retailers, increasing recurring revenues, making new acquisitions in strategic areas of retail, expanding in Latin America and the world and offering products and services to meet the customers' needs in commercial automation.

In this context, we highlight the new routines and operational capabilities, such as those related to technology acquisition and incorporation of companies, which bring new possibilities for the generation of value for investors and customers. These activities are the basis for continued innovation, as the acquired companies bring new technologies to be used in new value propositions and development of solutions for new verticals. Partnerships tied to investments in technology and the assimilation of these technologies become a powerful combination in creating and capturing value in the business model.

\subsection{Bematech's dynamic capabilities}

From the analysis of the business model, the results of the application of the adapted Pavlou and El Sawy model (2011) could be presented to 
identify the dynamic capacities translated into high-level routines, as well as to point out how these high-level routines modified the ordinary or operational capacities of Bematech; and then, the operational routines, to show the relationship between them and the dynamic capabilities.

\subsection{Bematech high-level routines}

A feature found in the company that may be the basis for its growth is a strategy focused on expansion. The content of the interviews and the analysis of the business model revealed that the entire Bematech structure is focused on expansion in markets, number of customers, products, services offered and above all, that there are internal and external forces that generate the need for change, but in this case, it could be said that the strategic direction and analysis of the scenarios is developed in the analysis of the information produced by the various sectors and teams, analyzed managers and the actions resulting from the analyses are decided at meetings. In this context, the company's high-level routines are developed, separated according to the Pavlou and El Sawy (2011) analysis model.

\subsection{Sensing}

In order to fulfill its strategic goals, Bematech constantly checks new acquisition opportunities in verticals of operation or in new market niches, such as the recent road transport market, vertical in which it starts acting after the acquisition of RJ, one of the leading companies in software for ticketing and controls of these companies: the routine is based on a team for analysis of such opportunities (Merger and acquisition team - M\&A), whose main function is identification and analysis of the acquisition opportunities. This team is divided in people who prospect companies, others who understand the acquisition candidate's business (degree of synergy with Bematech's business), and a team to analyze the impacts of the acquisition.

Another identified routine is the documentation of feedback from resellers and customers who call the call center, but in this case, it was not possible to identify the specific routine to organize this data and use it to bring future benefits.

According to the information technology (IT) director of Bematech, it is very important to check the compatibility of the acquired systems with the Bematech systems; there is a high cost of integration to be considered if the systems and the databases are completely incompatible. 


\subsection{Learning routines}

Bematech has routines to review the operational routines. The technical training programs represented by Bematech University are reviewed constantly. Bematech University was an initiative to build the qualification of partners, such as resellers, in the company's products and services and its main goal was the partners' loyalty. In addition to the technical area, the trainings include business representative training, such as training in marketing, finance and strategic management. Currently, several courses are offered at distance on the University site.

Procurement processes also reflect the learning routines. Such processes have influence throughout the company and are considered by the outreach director as the ones that bring more value to the company, as the efforts to integrate new technologies are fuel for innovation and incremental improvements in products and services. In this context, the company has professionals in the field of research and development in software and hardware, approximately two hundred professionals, who use routines to develop software, such as SCRUM methodology, an agile development methodology software.

\subsection{Seizing routines}

The importance given to the partners' loyalty and training can be perceived in a newer program: Bematech plus. The program is an example of review of operational capacity and aims at restructuring the relationship channels with customers through actions directed to equipment resellers and software partners.

According to the director of investor relations (IR), one of the main processes within the purchasing activity is the integration process. The challenge of creating a resource integration process between the acquired companies and Bematech made it create a position of board responsible for this part. This director's main goals are to integrate information technology resources, people, building infrastructure and processes of companies.

This integration team also acts in identifying new opportunities within the acquisition process, how to meet new verticals, new products and services, by developing the mix of products.

The committees are composed of directors and responsible for vertical operations, and they also play an important role in the integration of resources. These committees discuss problem solutions and action plans based on the company's strategies. 


\subsection{Coordination routines}

The "Bematech Mais" (Bematech plus) plays a role of reseller coordinator. Using the requests for information provided by retailers on site, you can perform a check on resales to encourage the sales mix of specific products or perform actions on specific niches of customers.

Another routine that must be aligned to the strategic goals of the company's annual activity review and direct the budget for the development of products targeted to the vertical target, for example, in recent years the company has invested in support services structures online, such as storage, processing and software cloud in management. This practice is aligned with the strategy of increasing recurring revenue from monthly payments or for certain periods of time using a software or rental space and processing in the cloud.

\subsection{Transforming}

The processing capacity is required when the organization has to deal with threats or exploit opportunities (Leih, Linden, \& Teece, 2014). It is the result of identification, learning, integration and coordination dynamic capabilities.

In this context, it can be said that the new business model is the result of this process. According to the director of investor relations, new development in goods and services each year is related to innovation routines, acquisition and exploration of market opportunities.

\subsection{Value creation and capture}

From the business model theory, we found value creation. According to Osterwalder and Pigneur (2010), value creation occurs from the progress of the proposed value or creating new value propositions. In this context, the addition of new value propositions and their acceptance by customers already demonstrates that there has been value creation and value capture possibility for the company. This increase business model about the value proposition and its ability to capture value for new channels that bring opportunities to win more customers and thus, create other sources of income, can be seen in Figure 2. 


\section{(figure 2)}

\section{VALUE CREATION IN THE BEMATECH'S BUSINESS MODEL}

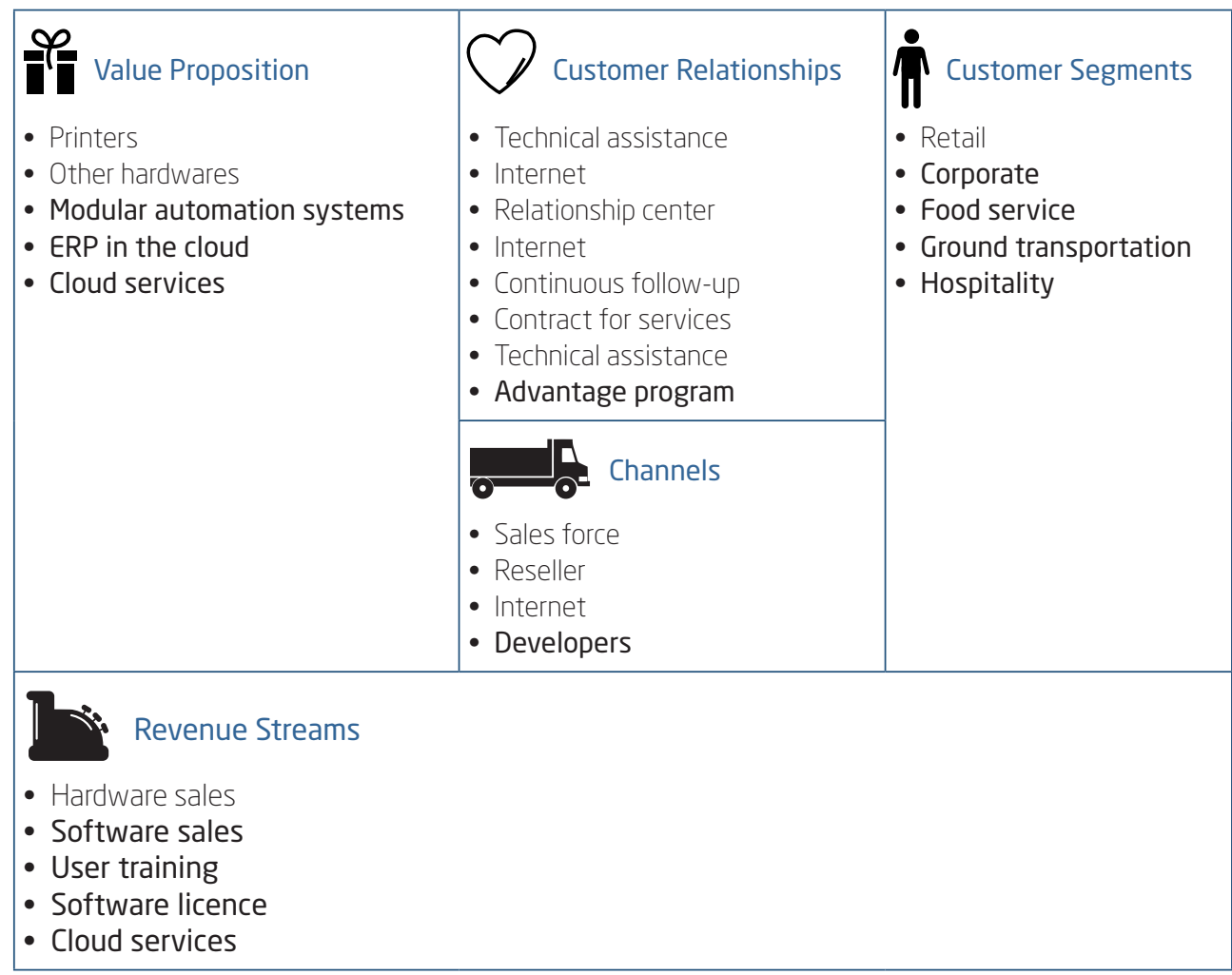

Source: Elaborated by the authors.

From the perspective of dynamic capabilities, high-level routines are related to the creation and value capture in business model and are responsible for the reconfiguration of operational capabilities and routines to meet new customer niches, offer new products and develop service channels.

The vision of dynamic capabilities brought the possibility of relating the routines of high-level Sensing, Seizing and Transforming (Figure 3), a task that would not be possible only from the analysis of the high-level routines in business model that create and capture value in business model. 


\section{(Figure 3)}

\section{HIGH-LEVEL ROUTINES THAT CREATE AND CAPTURE VALUE IN BUSINESS MODEL}

\begin{tabular}{|c|c|c|c|}
\hline Bematech & Sensing & Seizing & Transforming \\
\hline $\begin{array}{c}\text { Value } \\
\text { creation }\end{array}$ & $\begin{array}{l}\text { - Constant verification of } \\
\text { acquisition opportunities } \\
\text { UNUM (hotel industry), } \\
\text { RJ (road transport). } \\
\text { - Constant verification of } \\
\text { product creation } \\
\text { opportunity. }\end{array}$ & $\begin{array}{l}\text { - Programs of technical. } \\
\text { and commercial training } \\
\text { of channels (Bematech } \\
\text { University). } \\
\text { - Research and } \\
\text { development (200 } \\
\text { professionals). } \\
\text { - Committees. } \\
\text { - Rethink the business } \\
\text { through new channel } \\
\text { strategies with } \\
\text { well-defined rules and } \\
\text { policies (Bematech Plus). } \\
\text { - Analysis of feedback } \\
\text { from resellers and } \\
\text { customers. } \\
\text { - Product review for } \\
\text { improvement. }\end{array}$ & $\begin{array}{l}\text { - Software partner } \\
\text { management routines, } \\
\text { Bematech more. } \\
\text { - Budget for product } \\
\text { improvement } \\
\text { (investment in recurrent } \\
\text { revenue products). } \\
\text { - Reseller management } \\
\text { routines. }\end{array}$ \\
\hline $\begin{array}{c}\text { Value } \\
\text { Capture }\end{array}$ & $\begin{array}{l}\text { - Merge \& acquisition } \\
\text { Merge \& acquisition } \\
\text { team. } \\
\text { - Routines for feedback } \\
\text { from resellers and } \\
\text { customers. } \\
\text { - Product review for } \\
\text { improvement. }\end{array}$ & $\begin{array}{l}\text { - Verification of the } \\
\text { opportunities that the } \\
\text { acquisitions bring during } \\
\text { the process of } \\
\text { adjustments between } \\
\text { companies. } \\
\text { - Opportunities for new } \\
\text { products and services. } \\
\text { - Bematech more. } \\
\text { - Committees. } \\
\text { - Merge \& acquisition } \\
\text { team. }\end{array}$ & $\begin{array}{l}\text { - Development of new } \\
\text { products and services } \\
\text { annually (Multi-POS, } \\
\text { promotions engine and } \\
\text { Bematech Shop Mobile) } \\
\text { - FOOD SERVICE GDI } \\
\text { (indicator manager). } \\
\text { - Bematech PDV, rear web } \\
\text { chef for sale SaaS. } \\
\text { - Changes in the business } \\
\text { model. }\end{array}$ \\
\hline
\end{tabular}

After checking the high-level routines of the company, we can carry out the analysis of routines that have brought changes or created the perfect environment for such changes in the business model. Connections can be made to the extent that most of the changes in the business model are connected to one or more routines. The analysis allows one to check 
which business model elements the company is more focused on, in what the business model element has a greater connection with the high-level routines of the company.

\subsection{Connection between routines and changes in the business model}

\section{(Figure 4)}

\section{BUSINESS MODEL AND HIGH-LEVEL ROUTINES}

\begin{tabular}{|c|c|}
\hline Business model & High-level routines \\
\hline $\begin{array}{l}\text { New value propositions: modular } \\
\text { automation systems, ERP in the } \\
\text { cloud, cloud services }\end{array}$ & $\begin{array}{l}\text { - Constant verification of acquisition opportunities. } \\
\text { - Constant selection of product creation opportunity. } \\
\text { - Research and development (200 professionals). } \\
\text { - Analysis of feedback from customers and resellers. } \\
\text { - Reviewing products for improvements. } \\
\text { - Verification of the opportunities the acquisitions bring } \\
\text { during the process of adjustments between companies. } \\
\text { - Budget to improve products. } \\
\text { - Development of new products and services annually. }\end{array}$ \\
\hline $\begin{array}{l}\text { New customers: corporate, food } \\
\text { service, hospitality, ground } \\
\text { transportation }\end{array}$ & $\begin{array}{l}\text { - Verification of the opportunities the acquisitions bring } \\
\text { during the process of adjustments between companies. } \\
\text { - Constant verification of procurement opportunities. } \\
\text { - Merge \& acquisition team. }\end{array}$ \\
\hline New channel: agent developers & $\begin{array}{l}\text { - Rethinking the business through new channel strategies } \\
\text { with well-defined rules and policies (bematech mais). } \\
\text { - Technical and commercial training programs for channels } \\
\text { (bematech university). } \\
\text { - Software management routine partners, bematech more. } \\
\text { - reseller management routines. }\end{array}$ \\
\hline $\begin{array}{l}\text { New key activities: the acquisition } \\
\text { of technology, maintaining } \\
\text { partnerships, software development }\end{array}$ & $\begin{array}{l}\text { - Rethinking the business through new channel strategies } \\
\text { with well-defined rules and policies (bematech mais). } \\
\text { - Committees. } \\
\text { - Merge \& acquisition team. }\end{array}$ \\
\hline $\begin{array}{l}\text { New partners: software houses, } \\
\text { software companies, internal } \\
\text { developers }\end{array}$ & $\begin{array}{l}\text { - To rethink the business through new channel strategies } \\
\text { with well-defined rules and policies (bematech more). }\end{array}$ \\
\hline $\begin{array}{l}\text { New key resources: developers, } \\
\text { software }\end{array}$ & $\begin{array}{l}\text { - To rethink the business through new channel strategies } \\
\text { with well-defined rules and policies (bematech more). }\end{array}$ \\
\hline $\begin{array}{l}\text { New customer relationships: benefits } \\
\text { program for customers }\end{array}$ & $\begin{array}{l}\text { - Budget for product improvements (investment in } \\
\text { recurring revenue products). }\end{array}$ \\
\hline
\end{tabular}

Source: Elaborated by the authors. 
Figure 4 demonstrates that the company Bematech maintains its focus on creating new value propositions, since most of its high-level routines identified in the study are focused on this element of the business model. Consequently, the company will have the potential to serve more customer niches and develop new sources of revenue.

\section{DISCUSSION}

An indication of the higher capacity of the new model for the increase in revenues was obtained by checking the economic results recorded in the financial statements of the company Bematech. There was an increase in revenues, mainly in recurring revenues - those from licensing software and systems to use software as service (SAS), such as Enterprise resource planning (ERP) in the cloud. The increase in revenues alone would not be a robust evidence that the new business model is more efficient to generate financial returns; however, the accounting information, documents and interviews of people responsible for the financial statements indicated a growth in the proportion of recurring revenues compared to the total revenues of the company. The survey of this information in recent years demonstrates an upward trend in these revenues, that is, evidence that the new model has shown an improvement in the ability to generate revenues and better economic results.

Dynamic capabilities enabled to understand the value creation process mediated by operational capabilities, and the case studies reaffirmed the trend of the dynamic capabilities theory in representing, with quality, a theoretical framework for the analysis of aspects related to the creation of value and business models.

In this context, if the analysis was limited to the business model and did not bring the perspective of dynamic capabilities, it would be possible to obtain a list of what has changed in the business model; however, the actions that caused such changes could not be understood in the analysis of the business model components.

It could be seen, especially in interviews with managers, that the highlevel routines were developed by the senior management and that stocks of high-level routines require the manager to be engaged effectively. This information confirms the Leih, Linden, and Teece's (2014) statement that the manager's role is essential both in the creation of high-level routines, as the harvesting phase, and the results from these routines, that is, if the 
information obtained from the capabilities dynamics, such as identifying an opportunity, is not exploited or understood to implement a change in the business model, such routines will be useless.

As for the process of change and value creation, it can be assumed that current business models would not exist if there were no technological changes. Business models have been modified by checking the value creation potential of new technological resources or those existing and already available in companies, i.e., the business model was designed after checking the resources within the company. According to the company's managers, the combination of these features, together with the creation of different business models, enabled the company to create a differentiated value proposition related to competitors. These new proposals, implemented and accepted by customers, meant the value created by the company and the ability to capture value.

Some routines have played an important role in changing the business model, such as those in surveys to identify new acquisitions, learning routines to employ the technologies acquired in mergers, integration routines of acquired companies and product review routines to detect opportunities for improvement.

The acquisitions include two moments of investments: the acquisition of the company's control and the cost of integrating the new company to Bematech.

Therefore, Bematech has the feature of acquiring the technologies it needs from financial transactions involving large amounts. The development of new products and services is a consequence of the technologies built into the business model.

It was noticed that Bematech used the technological infrastructure to bring the actors of the business model. Evidence of this are the joint efforts in information technology to benefit resellers and software partners in a complex channel strategy. This approach reveals the importance attributed to the sales channels and the reach in the market. Another important part of the use of information technology is the development of products and services, these result from the routines of acquisition and integration of new technologies and innovation processes in the areas of software and hardware.

In short, the connection between the business model and dynamic capabilities in this study occurred multilaterally, and the high-level routines were fundamental to the innovation of the business model and impacted various elements of the business model. Such routines acted as true sources of change, providing the ideal environment for change. 


\section{CONCLUSIONS}

Theories related to the business model, value creation and dynamic capabilities demonstrate the existence of overlaps and important relationships, when addressing topics, such as strategy and organizational structure. In this context, the vision of dynamic capabilities allowed the process of creating value in business models driven by changes in the technological structure of the companies, object of this study, to be explored, which made the achievement of the overall goals of the work possible.

The theory of business models proved to be multidisciplinary, a view that was formed under the influence of other theories and practical application in any organization. The analysis of business models enabled bringing an analytical overview of the information technology and cleared its role in creating value for the company.

Understanding the process of creating value in the proposed goal of the work could have been addressed from other perspectives, such as resourcebased view (RBV), the theory of transaction costs, contingency theory, among others.

In the demonstration of the business model, it was not possible to verify the dynamic capacity as part of the business model; however, it can be a confirmation in this particular case, since it is a single case study. Therefore, in the case under analysis, each dynamic capacity could be considered as an external factor to the business model. The key activities observed in the representation of the business model could be those closer to a high-level routine; however, it was observed that the high-level routines that altered the key activities are not confused. Some ordinary routines might be observed in key business model activities, for example, acquiring partnership, maintaining partnerships and software development. These activities are necessary to the business model, since they are part of the logic that explains how the company creates and captures value, but they cannot be considered high-level routines, since they do not modify other routines. Therefore, it was possible to observe that the dynamic capacities change business models; however, it was not possible to observe whether business models participate in the development of dynamic capacities.

\section{$\int$ REFERENCES}

Anderson, J. C., \& Narus, J. A. (1998). Business marketing: understand what customers value. Harvard business review, 76, 53-67. 
Augier, M., \& Teece, D. J. (2008). Strategy as evolution with design: The foundations of dynamic capabilities and the role of managers in the economic system. Organization studies, 29(8-9), 1187-1208. doi 10.1177/017084060 8094776

Baden-Fuller, C., \& Morgan, M. S. (2010). Business models as models. Long range planning, 43(2), 156-171. doi 10.1016/j.lrp.2010.02.005

Barney, J. (1991). Firm resources and sustained competitive advantage. Journal of management, 17(1), 99-120. doi 10.1177/014920639101700108

Barney, J. B., \& Arikan, A. M. (2001). The resource-based view: Origins and implications. Handbook of strategic management, 124188. doi 10.1111/b.97806 31218616.2006.00009.x

Bock, A. J., Opsahl, T., George, G., \& Gann, D. M. (2012). The effects of culture and structure on strategic flexibility during business model innovation.JournalofManagement Studies, 49(2),279-305. doi 10.1111/j.1467-6486. 2011.01030.x

Bowman, C., \& Ambrosini, V. (2000). Value creation versus value capture: towards a coherent definition of value in strategy. British Journal of Management, $11(1), 1-15$.

Boulton, R., Libert, B., \& Samek, S. M. (2000). Cracking the Value Code: How successful businesses are creating wealth in the New Economy. New York, NY: HarperBusiness. doi 10.1111/1467-8551.00147

Boulton, R. E., Libert, B. D., \& Samek, S. M. (2000). A business model for the new economy. Journal of Business Strategy, 21(4), 29-35. doi 10.1108/ eb040102

Cavalcante, S., Kesting, P., \& Ulhøi, J. (2011). Business model dynamics and innovation: (re) establishing the missing linkages. Management Decision, 49(8), 1327-1342. doi: 10.1108/00251741111163142

Eisenhardt, K. M., \& Martin, J. A. (2000). Dynamic capabilities: what are they? Strategic management journal, 1105-1121. doi 10.1002/1097-0266 (200010/11)21:10/ 11<1105::AID-SMJ133>3.0.CO;2-E

Grant, R. M. (1996). Toward a knowledge-based theory of the firm. Strategic management journal, 17(S2), 109-122. doi 10.1002/smj.4250171110

Helfat, C. E., Finkelstein, S., Mitchell, W., Peteraf, M., Singh, H., Teece, D., \& Winter, S. G. (2009). Dynamic capabilities: Understanding strategic change in organizations.

John Wiley \& Sons.Henderson, R., \& Cockburn, I. (1994). Measuring competence? Exploring firm effects in pharmaceutical research.Strategic management journal, 15(S1), 63-84. doi 10.1002/smj.4250150906 
Katkalo, V. S., Pitelis, C. N., \& Teece, D. J. (2010). Introduction: On the nature and scope of dynamic capabilities. Industrial and Corporate Change, 19(4), 1175-1186. doi 10.1093/icc/dtq026

Kraaijenbrink, J., Spender, J. C., \& Groen, A. J. (2010). The resource-based view: a review and assessment of its critiques. Journal of management, 36(1), 349-372. doi 10.1177/0149206309350775

Leih, S., Linden, G., \& Teece, D. (2014). Business model innovation and organizational design: A dynamic capabilities perspective. Oxford: Oxford University Press. Retrieved from https://papers.ssrn.com/sol3/papers. cfm?abstract_id $=2423191$

Lindgreen, A., Hingley, M. K., Grant, D. B., \& Morgan, R. E. (2012). Value in business and industrial marketing: Past, present, and future. Industrial Marketing Management, 41(1), 207-214. doi 10.1016/j.indmarman.2011. 11.025

Magretta, J. (2002). Why business models matter. Harvard Business Review, 80(5), p. 86-92. Retrieved from https://hbr.org/2002/05/why-businessmodels-matter

Osterwalder, A., \& Pigneur, Y. (2010). Business model generation: a handbook for visionaries, game changers, and challengers. Journal of Product Innovation Management, 26(6). doi 10.1111/j.1540-5885.2012.00977_2

Osterwalder, A. (2004). The business model ontology: A proposition in a design science approach. Master these, Ecole des Hautes Etudes Commerciales, Université de Lausanne, Lausanne, Switzerland.

Pavlou, P. A., \& El Sawy, O. A. (2011). Understanding the elusive black box ofdynamiccapabilities.Decision Sciences, 42 (1),239-273. doi 10.1111/j.15405915.2010.00287.x

Penrose, E. T. (1995). The Theory of the Growth of the Firm. Oxford University Press, USA. doi: 10.1093/0198289774.001.0001

Porter, M. E. (1985). Competitive advantage: creating and sustaining superior performance. Revista de Administração de Empresas, 25(2). doi 10.1590/ S0034-75901985000200009

Teece, D. J., Pisano, G., \& Shuen, A. (1997). Dynamic capabilities and strategic management. Strategic management journal, 509-533. doi 10.1002/ (SICI) 1097-0266(199708) 18:7<509::AID-SMJ882>3.0.CO;2-Z

Teece, D. J. (2010). Business models, business strategy and innovation. Long range planning, 43(2), 172-194. doi 10.1016/j.lrp.2009.07.003 
Teece, D. J. (2007). Explicating dynamic capabilities: the nature and microfoundations of (sustainable) enterprise performance. Strategic management journal, 28(13), 1319-1350. doi 10.1002/smj.640

Teece, D. J. (2012). Dynamic capabilities: Routines versus entrepreneurial action. Journal of Management Studies, 49(8), 1395-1401. doi 10.1111/j.14676486.2012.01080.x

Teece, D. J., \& Pisano, G. (1994). The dynamic capabilities of firms: an introduction. Industrial and corporate change, 3(3), 537-556. doi 10.1093/ icc/3.3.537-a

Vodovoz, E. (2015). As mudanças na tecnologia da informação e a criação de valor no modelo de negócio. http://hdl.handle.net/1884/39878

Winter, S. G. (2003). Understanding dynamic capabilities. Strategic management journal, 24(10), 991-995. doi: 10.1002/smj.318

Zott, C., Amit, R., \& Massa, L. (2011). The business model: recent developments and future research. Journal of management, 37(4), 1019-1042. doi 10.1177/0149206311406265

\title{
$\int$ ABOUT THE AUTHORS
}

\author{
ELIC VODOVOZ \\ Master degree in Business, \\ Universidade Federal do Paraná (UFPR). \\ Professor, ESIC Business \& Marketing School. \\ Rua Curupaitis, 1963, - Portão - PR - Brasil - CEP 80330-030 \\ E-mail: elicvz@me.com \\ MARCIA RAMOS MAY \\ $\mathrm{PhD}$ in Business, \\ Universidade de São Paulo (USP). \\ Professor, Universidade Federal do Paraná (UFPR). \\ Rua prefeito Lothário Meissner 632, Jardim Botânico - Curitiba - PR - CEP 80210-170 \\ E-mail:marciamay@gmail.com
}

